\title{
MENGOPTIMALKAN SKEMATA SISWA MENGGUNAKAN LEMBAR KERJA SISWA BERBASIS ETNOMATEMATIKA: ANYAMAN DAN TENUNAN MASYARAKAT TTU
}

\author{
Maria Dionesia Kofi ${ }^{1 *}$, Selestina Nahak ${ }^{2}$ \\ ${ }^{1}$ Mahasiswa Pendidikan Matematika Universitas Timor, ${ }^{2}$ Universitas Timor \\ *desikofi@yahoo.com
}

Dikirim: 05 April 2020. Diterima: 09 April 2020. Dipublikasikan: 31 Juli 2020

\begin{abstract}
ABSTRAK
Salah satu inovasi dalam pembelajaran matematika sebagai upaya untuk mengoptimalkan skemata siswa adalah melalui pengembangan LKS menggunakan pendekatan etnomatematika. Tujuan penulisan ini adalah untuk mengoptimalkan skemata siswa melalui pembelajaran menggunakan LKS yang dikembangkan dengan pendekatan etnomatematika. Pengembangan LKS ini menggunakan model Plomp. Untuk mengetahui kevalidan, kepraktisan, dan keefektifan LKS, dilakukan pengumpulan data melalui validasi LKS, observasi guru dan siswa, melakukan tes hasil belajar dan pengisian angket respon siswa. Untuk mengetahui hasil optimalisasi skemata siswa dilakukan pengumpulan data melalui pengisian instrumen ketercapaian skemata siswa berdasarkan hasil penyelesaian LKS. Analisis data dilakukan dengan metode kuantitatif-deskriptif. Kevalidan LKS memenuhi kriteria valid sebesar 4,33. Kepraktisan LKS memenuhi kriteria sangat baik dilihat dari Tingkat Kemampuan Guru mengelola pembelajaran sebesar 4,55 dan aktivitas siswa efektif dengan persentase 98,70\% sesuai waktu ideal yang ditetapkan. Keefektifan LKS terpenuhi berdasarkan kriteria ketuntasan klasikal sebesar 85,19\% dan respon siswa terhadap komponen pembelajaran positif. Rata-rata ketercapaian skemata siswa pada hasil penyelesaian LKS 2 sebesar 3,58 lebih besar dari LKS 1 sebesar 3,00. Penggunaan LKS berbasis etnomatematika ini dapat mengoptimalkan skemata siswa.

Kata kunci: etnomatematika, LKS, skemata.
\end{abstract}

\begin{abstract}
One of innovation in learning mathematics, as effort for optimizing student's schemata, is through developing student worksheets (SW) using ethnomathematics approach. This study aimed to optimizing student's schemata through learning mathematics using SW developed by ethnomathematics approach. Developing SW in this study using Plomp model. To know the acceptance, implement, and effectiveness of $S W$, data is collected by validation of $S W$, teacher and student observation, learning outcomes, and student's questionnaire. While to know result of optimizing student schemata, data is collected through instrument of student schemata achievement based on student answer on SW. The data is analyzed quantitavely and descriptively. The findings are SW is satisfied acceptance which is "valid" criteria as 4.33 at the same time, implement of SW achieved "very good" criteria as 4.55 based on teacher ability in classroom management and student activities belongs to "effective" criteria as $98.70 \%$ refer to provided time. The effectiveness of $S W$ is achieved based on class average as $85,19 \%$ and student response toward learning activities is positive. Average of achievement of student schemata on SW 2 as 3,58 greater than SW 1 as 3,00. In conclusion, using SW-based ethnomathematics could optimize student schemata.
\end{abstract}

Keywords: ethnomathematics, student worksheets, schemata.

\section{Pendahuluan}

Dalam teori perkembangan Piaget, terdapat istilah skemata yang diartikan sebagai pola perilaku atau berpikir yang digunakan individu dalam menangani objek-objek di dunia (Trianto, 2010 : 70). Struktur skemata sangat penting dalam pembentukan kognitif siswa, di mana struktur kognitif ini diperlukan siswa dalam merespons lingkungan dengan pengintegrasian informasi ke dalam skema yang 


\section{Range: Jurnal Pendidikan Matematika Vol. 2 No. 1 Tahun 2020 Maria Dionesia Kofi, dkk.}

telah ada yang disebut asimilasi, dan melakukan akomodasi yaitu memodifikasi skema-skema agar sesuai dengan situasi baru.

Fenomena pembelajaran matematika di kelas yang selama ini terjadi dideskripsikan sebagai berikut: 1) siswa diajarkan dengan materi yang abstrak, 2) pembelajaran cenderung menggunakan buku teks, guru dan siswa menggunakan buku pegangan sendiri yang konteksnya masih jauh dari pengalaman siswa, 3) siswa tidak pernah diminta untuk menyampaikan refleksi hasil belajar, dan 4) siswa tidak termotivasi dalam belajar. Akibatnya terkadang dalam proses pembelajaran siswa cepat merasa bosan dan menganggap mata pelajaran matematika itu sulit. Hal-hal ini dimungkinkan terjadi karena beberapa faktor, salah satunya skemata siswa yang tidak dioptimalkan sehingga proses asimilasi dan akomodasi tidak berjalan secara sempurna. Hal ini berdampak pada pemahaman tentang hal baru yang sulit diterima. Skema yang sudah dimiliki siswa yang dapat berasal dari tradisi, kebiasaan, simbol-simbol dalam aktivitas budaya yang diidentifikasi sebagai etnomatematika kurang dimanfaatkan guru dalam pembelajaran matematika. Ini menyebabkan proses asimilasi dan akomodasi kurang optimal.

Etnomatematika sebagai suatu ilmu yang digunakan untuk memahami bagaimana matematika diadaptasi dari sebuah budaya, melalui objek budaya yang mengandung konsep matematika pada masyarakat tertentu (Hardiarti, 2017:100-101) dan sebagai proses mempraktekkan konsep matematika dalam pembelajaran dengan kearifan budaya lokal (Richardo, 2016 : 119), menempatkan etnomatematika sebagai salah satu pendekatan pembelajaran yang mengacu pada budaya lokal yang dapat diterapkan untuk menggali dan menemukan konsep-konsep matematika dari budaya suatu masyarakat. Dengan demikian suatu budaya dapat dieksplorasi untuk menemukan kekayaan bernalar secara matematik. Selain itu budaya juga dapat dipandang sebagai tempat terjadinya kebiasaan-kebiasaan yang memunculkan konsep, ilmu dan pengetahuan tentang matematika yang dapat diimplementasikan dalam pembelajaran.

Penelitian terdahulu oleh Deda \& Disnawati (2017: 208) mengkaji hubungan motif kain tenun masyarakat suku Dawan-Timor dengan matematika sekolah. Terdapat motif Buna, Sotis, dan Futus yang memiliki hubungan dengan pembelajaran konsep geometri, seperti pengenalan konsep segi empat, garis lurus, dan konsep pencerminan. Pemanfaatan motif kain tenun sebagai salah satu potensi lokal masyarakat kefamenanu dapat digunakan sebagai konteks pembelajaran matematika yang dapat meningkatkan kretivitas guru (Amsikan \& Deda, 2018). Penjelasan lebih tentang konsep-konsep geometri dalam motif kain tenun masyarakat Kefamenanu dan juga dapat digunakan untuk menjembatani pemahaman siswa dalam pembelajaran matematika sekolah (Deda \& Amsikan, 2019). Funan dan Mamoh (2019) juga telah melihat konsep geometri yang terdapat pada Uem Le'u Insana. Selanjutnya pada hasil eksplorasi awal oleh Disnawati dan Nahak (2019:70) terhadap konteks budaya Timor untuk diintegrasikan dalam pengembangan LKS berbasis etnomatematika, produk budaya Timor dapat dikelompokkan ke dalam enam jenis konteks antara lain: aktivitas menenun dan aneka motifnya, rumah adat, makanan tradisonal, tarian tradisonal, kerajinan tangan/anyaman serta cerita rakyat. Berbagai konteks budaya Timor ini dapat digunakan dalam pembelajaran matematika.

Dalam pembelajaran matematika sekolah yaitu matematika yang diajarkan pada Pendidikan Dasar dan Menengah, siswa dibiasakan untuk memperoleh pemahaman melalui pengalaman tentang sifat-sifat yang dimiliki dan yang tidak dimiliki dari sekumpulan objek (abstraksi) (Ar, dkk. 2001:54-55). Matematika berperan sebagai sarana mengembangkan daya nalar, karena belajar matematika berarti belajar cara mengembangkan kemampuan berpikir (Rasyid, dkk. 2017 : 171). Dengan ini perlu dilakukan penyesuaian antara matematika sekolah dengan tingkat perkembangan kognitif siswa melalui pemahaman konsep berdasarkan pengalaman (hal-hal konkret). Proses memahami ini dapat dibentuk dari skemata yang telah dimiliki.

Piaget mengartikan skemata ini sebagai struktur kognitif (kumpulan dari skema-skema). Seorang individu dapat mengikat, memahami dan memberi respons terhadap stimulus karena bekerjanya skemata ini yaitu melalui proses asimilasi dan akomodasi (Ar, dkk 2001:38). Seberapa besar lingkungan dapat dipahami atau direspons bergantung pada berbagai skemata yang tersedia bagi organisme (Hergenhahn \& Olson, 2008:314). Dalam proses pembelajaran siswa memahami sesuatu melalui proses ini yaitu memahami konsep baru atau hal abstrak dengan menghubungkannya dengan pengalaman / skemata yang 


\section{Range: Jurnal Pendidikan Matematika Vol. 2 No. 1 Tahun 2020 Maria Dionesia Kofi, dkk.}

telah dimiliki. Sehingga pemanfaatan skemata menjadi modal belajar siswa. Dari beberapa pendapat ini proses belajar dapat dilakukan secara efektif dengan menciptakan kondisi belajar bermakna, mengkonstruksi pengetahuan berdasarkan pada pengalaman siswa dalam lingkungan.

Permasalahan sekarang adalah bagaimana mengoptimalkan skemata siswa dalam pembelajaran matematika. Salah satu solusi yang menurut penulis dapat dijadikan alternatif yaitu menggunakan LKS berbasis etnomatematika. LKS merupakan kumpulan panduan yang disusun secara sistematis oleh guru, berupa kegiatan ataupun latihan untuk digunakan siswa dalam melakukan proses pembelajaran melalui kegiatan penyelidikan atau pemecahan masalah (Iskandar \& Radytia, 2017: 169). Dengan kata lain LKS merupakan alat yang berisikan kegiatan-kegiatan yang harus dilakukan siswa dalam proses pembelajaran dengan berbagai konteks/pendekatan yang relevan dengan kebutuhan dan karakteristik siswa. LKS yang digunakan harus memenuhi kriteria valid, praktis, dan efektif. LKS yang sudah memenuhi kriteria ini dapat digunakan untuk mencapai tujuan penulisan ini yaitu mengoptimalkan skemata siswa menggunakan LKS berbasis etnomatematika. Pendekatan etnomatematika yang dimaksud di sini adalah anyaman lokal (tempat sirih pinang/kabi dan tikar) dan tenunan masyarakat kabupaten Timor Tengah Utara.

\section{Metode Penelitian}

Metode penelitian ini menggunakan penelitian pengembangan untuk mengembangkan LKS, mengacu pada model Plomp yang terdiri atas lima tahap yaitu investigasi awal, desain, realisasi/konstruksi, tes-evaluasi-revisi, implementasi (Rochmad, 2012: 65-67). Selanjutnya dilakukan penilaian hasil penyelesaian LKS untuk melihat ketercapaian skemata siswa dan mendeskripsikannya.

Penelitian dilaksanakan di SMPN 1 Miomaffo Barat pada Tahun Ajaran 2018/2019. Subjek dalam penelitian ini adalah siswa-siswi kelas VII B yang berjumlah 27 orang. Pengumpulan data dilakukan melalui validasi LKS menggunakan instrumen berupa lembar validasi LKS, uji keterbacaan LKS menggunakan instrumen berupa angket keterbacaan LKS, observasi yang dilakukan untuk memperoleh data kepraktisan LKS dengan mengamati Tingkat Kemampuan Guru mengelola pembelajaran (TKG) dan aktivitas siswa menggunakan instrumen berupa lembar observasi guru dan siswa, tes hasil belajar dan respon siswa untuk memperoleh data keefektifan LKS menggunakan instrumen berupa soal tes dan angket respon siswa, serta penilaian hasil penyelesaian LKS untuk mengetahui optimalisasi skemata siswa menggunakan instrumen berupa lembar penilaian hasil penyelesaian LKS.

Data dianalisis secara kuantitatif-deskriptif meliputi:

1. Analisis data hasil validasi LKS, dengan menghitung rata-rata $(\overline{\mathrm{x}})$ dari nilai yang diberikan oleh setiap validator untuk setiap dokumen yang diberikan kemudian dibandingkan dengan selang kriteria. LKS akan digunakan jika berada pada kategori minimal cukup valid, yaitu pada interval $2,50 \leq \overline{\mathrm{x}}<3,50$ (Mamoh, $2016: 13$ ).

2. Analisis data keterbacaan LKS, menggunakan statistik deskriptif. LKS dapat digunakan untuk uji coba lapangan jika rata-rata total keterbacaan LKS berada pada kategori minimal baik pada interval $2,2 \leq \overline{\mathrm{x}}<3,1$.

3. Analisis data kemampuan guru mengelola pembelajaran, menggunakan statistik deskriptif dengan skor rata-rata Tingkat Kemampuan Guru (TKG). LKS dikatakan efektif jika rata-rata total TKG pada semua aspek dinilai berada pada kategori minimal cukup baik, yaitu pada interval 2,50 $\leq \mathrm{TKG}<3,50$ (Mamoh, $2016:$ 13).

4. Analisis data aktivitas siswa, menggunakan statistik deskriptif dengan persentasi dari setiap respon siswa yaitu jumlah respon positif tiap aspek yang muncul dibagi jumlah seluruh siswa dikali $100 \%$. Aktivitas siswa dikatakan efektif jika persentase aktivitas siswa yang mendukung pembelajaran lebih besar dari persentase aktivitas siswa yang tidak mendukung pembelajaran (Mamoh, 2016 : 13).

5. Analisis data respon siswa, menggunakan statistik deskriptif. Respon siswa dikatakan positif jika persentase jawaban positif siswa untuk setiap aspek yang direspon pada setiap komponen pembelajaran minimal 70\% (Mamoh, $2016: 13$ ).

6. Analisis hasil belajar siswa, dihitung secara individu dan klasikal, mengacu pada Kriteria Ketuntasan Minimal yang ditetapkan oleh sekolah yaitu minimal 78. 


\section{Range: Jurnal Pendidikan Matematika Vol. 2 No. 1 Tahun 2020 Maria Dionesia Kofi, dkk.}

7. Analisis data optimalisasi, menggunakan statistik deskriptif dengan skor rata-rata ketercapaian skemata siswa pada penyelesaian LKS berdasarkan kategori/nomor soal. Skemata siswa dikatakan optimal jika perolehan rata-rata ketercapaian skemata siswa pada hasil penyelesaian LKS 2 lebih besar dari LKS 1.

\section{Hasil Penelitian dan Pembahasan}

\section{Hasil}

\section{Pengembangan LKS Berbasis Etnomatematika}

Pengembangan LKS berbasis etnomatematika menggunakan konteks anyaman lokal (kabi dan tikar) serta tenunan yang mengacu pada model Plomp adalah langkah inovasi dalam mengoptimalkan skemata siswa. Sesuai prosedurnya tahapan pengembangan Plomp terdiri atas lima tahapan, tetapi dalam penelitian ini hanya dilakukan sampai tahap keempat. Hasil penelitian ini diuraikan sebagai berikut.

\section{A. Tahap Investigasi Awal (preliminary investigation)}

1. Analisis Kurikulum

Kurikulum yang digunakan di sekolah yang merupakan lokasi penelitian adalah kurikulum 2013. Guru sudah menggunakan pendekatan sesuai dengan anjuran K13 yaitu pendekatan saintifik dan kontekstual. Namun guru belum menerapkan pendekatan etnomatematika yang juga dapat membantu siswa mengkonstruksi pengetahuan melalui budaya di sekitarnya. Selain itu sumber belajar masih terbatas pada perangkat yang diterbitkan Depdiknas yang oleh guru dinilai penggunaan konteksnya masih terlalu umum atau hanya disesuaikan dengan kelompok siswa di daerah tertentu. Sumber belajar seperti LKS belum digunakan dan lebih lagi LKS dengan pendekatan etnomatematika.

2. Analisis Materi

Dari hasil analisis Kompetensi Dasar dan indikator pencapaian kompetensi dalam kurikulum 2013, peneliti mengambil materi segiempat dengan sub pokok bahasan Persegipanjang dan Persegi. Dalam pengembangan LKS ini peneliti memfokuskan materi pada menemukan sifat-sifat persegipanjang dan persegi serta definisinya, dan menyelesaikan masalah nyata yang berkaitan dengan sifat-sifat persegipanjang dan persegi. Hasilnya disajikan dalam tabel berikut.

Tabel 1. Hasil Analisis Materi

\begin{tabular}{ll}
\hline Kompetensi Dasar & \multicolumn{2}{c}{ Indikator } \\
\hline $\begin{array}{l}\text { 3.1 Manganalisis berbagai bangun datar segiempat 3.1.1 } \\
\text { (persegi, persegipanjang, belah ketupat, jajar }\end{array}$ & $\begin{array}{l}\text { Menemukan sifat - sifat persegipanjang dan } \\
\text { persegi, ditinjau dari sisi, sudut dan } \\
\text { diagonalnya. }\end{array}$ \\
$\begin{array}{l}\text { genjang, trapesium, dan layang-layang) dan } \\
\text { segitiga berdasarkan sisi, sudut, dan hubungan 3.1.2 }\end{array}$ & $\begin{array}{l}\text { Mendefinisikan persegi panjang dan persegi, } \\
\text { menurut sifatnya. }\end{array}$ \\
$\begin{array}{l}\text { antar sisi dan antar sudut. } \\
\text { 4.1 Menyelesaikan masalah yang berkaitan 4.1.1 }\end{array}$ & $\begin{array}{l}\text { Menyelesaikan masalah dalam kehidupan } \\
\text { dengan bangun datar segiempat (persegi, } \\
\text { nyata yang berkaitan dengan sifat-sifat }\end{array}$ \\
$\begin{array}{l}\text { persegipanjang, belahketupat, jajargenjang, } \\
\text { trapesium, dan layang-layang)dan segitiga. }\end{array}$ & bangun datar segiempat (persegi panjang dan \\
persegi)
\end{tabular}

3. Analisis Siswa

Berdasarkan perkembangan kognitif, rata-rata siswa berada pada tahap operasional formal di mana pola berpikir siswa sudah meliputi proses-proses yang kompleks yaitu berpikir secara abstrak dan logis. Namun siswa pada tahap ini juga masih membutuhkan objek-objek konkret untuk dapat memahami materi dengan baik, salah satunya dengan objek budaya lokal yang sangat sering ditemukan siswa.

Tempat tinggal siswa berada di sekitar wilayah kecamatan Miomaffo Barat-TTU, yang masih memelihara beberapa tradisi dan kekayaan budaya lokal seperti pembuatan dan penggunaan anyaman lokal ( $k a b i$ dan tikar) serta tenunan. Lingkungan sekitar siswa sangat mendukung terpeliharanya budaya tersebut melalui kebiasaan-kebiasaan masyarakat, sehingga pemanfaatan anyaman dan tenunan 


\section{Range: Jurnal Pendidikan Matematika Vol. 2 No. 1 Tahun 2020 Maria Dionesia Kofi, dkk.}

dalam pengembangan LKS ini akan membantu siswa belajar dari apa yang diketahui ke apa yang tidak diketahui untuk dapat mengoptimalkan skemata siswa.

\section{B. Tahap perancangan (design)}

Peneliti mendesain LKS dengan memanfaatkan anyaman dan tenunan masyarakat TTU. Pada desain awal ini peneliti juga merancang instrumen penelitian meliputi: instrumen kevalidan LKS yaitu lembar validasi LKS, instrumen kepraktisan terdiri dari lembar pengamatan kemampuan guru mengelola pembelajaran dan lembar pengamatan aktivitas siswa dalam pembelajaran, instrumen keefektifan yang terdiri dari angket respon siswa dan tes hasil belajar, angket keterbacaan LKS, dan instrumen ketercapaian skemata siswa berupa lembar penilaian hasil penyelesaian LKS

\section{Tahap realisasi/konstruksi (realization/constrution)}

Prototipe 1 telah dihasilkan pada tahap ini yaitu perangkat LKS pada materi Segiempat menggunakan konteks anyaman dan tenunan dengan memperhatikan aspek format, bahasa, dan isi. LKS yang dihasilkan sebanyak 2 buah untuk 2 kali pertemuan. Selain itu, telah dihasilkan instrumen yang dibutuhkan dalam penelitian.

D. Tahap tes, evaluasi, dan revisi (test, evaluation, revision)

Tahap ini mencakup kegiatan tes, evaluasi, dan revisi untuk mempertimbangkan mutu dari rancangan LKS dengan konteks anyaman dan tenunan yang dikembangkan. Kegiatan ini meliputi kegiatan validasi dan uji coba LKS.

1. Validasi LKS

Aspek-aspek yang dinilai dalam validasi LKS ini meliputi format, bahasa, dan isi. Kevalidan LKS terukur dari hasil penilaian para validator yang terdiri dari 2 orang dosen matematika dan 1 orang guru matematika. Rata-rata total hasil validasi adalah 4,33 menunjukkan LKS valid. Berdasakan saran ahli, LKS dapat digunakan untuk uji coba setelah dilakukan revisi kecil. Berikut contoh LKS sebelum dan sesudah validasi.

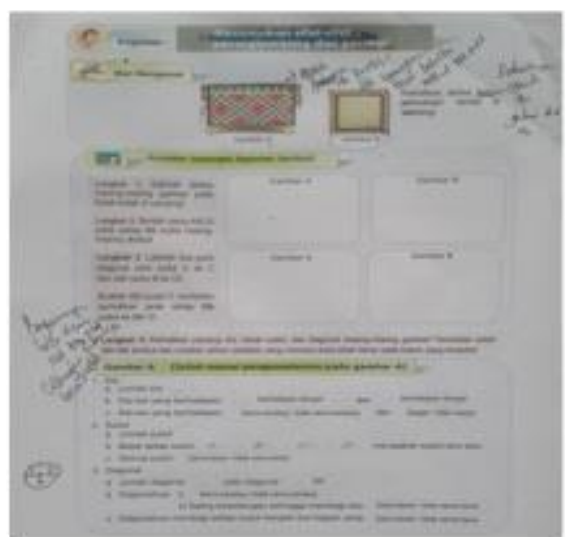

Gambar 1. LKS 1 sebelum divalidasi

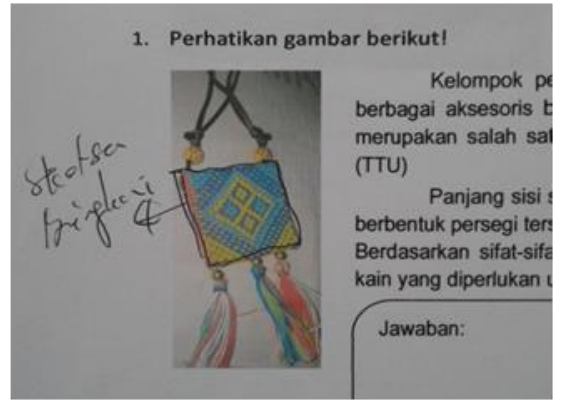

Gambar 3. LKS 2 sebelum divalidasi

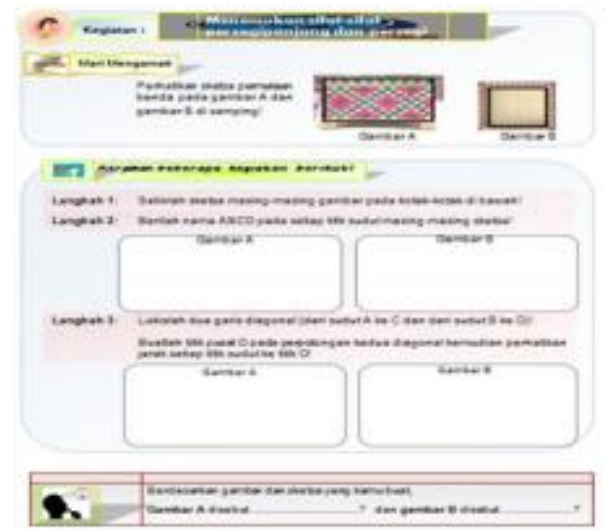

Gambar 2. LKS 1 setelah divalidasi

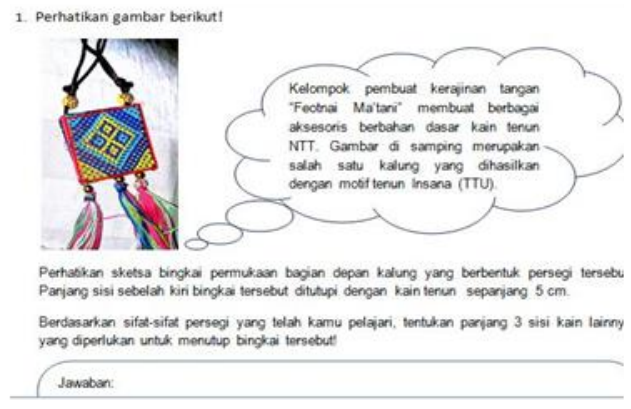

Gambar 4. LKS 2 setelah divalidasi 


\section{Range: Jurnal Pendidikan Matematika Vol. 2 No. 1 Tahun 2020 Maria Dionesia Kofi, dkk.}

\section{Uji Coba Keterbacaan LKS}

LKS yang telah valid diberikan kepada 3 orang siswa kelas VII B untuk mengetahui tingkat keterbacaan LKS. Siswa diminta membaca dan memahami LKS kemudian memberi penilaian pada angket keterbacaan LKS. Secara keseluruhan penilaian siswa terhadap LKS baik. Rata-rata total keterbacaan LKS sebesar 3,25 (sangat baik) sehingga LKS layak digunakan untuk uji coba lapangan.

3. Uji Coba Lapangan

LKS diujicobakan kepada 27 orang siswa untuk mengetahui kepraktisan dan keefektifan LKS. Hasilnya diuraikan sebagai berikut.

a. Kepraktisan LKS

Kepraktisan LKS dengan konteks anyaman dan tenunan memenuhi kriteria sangat baik dilihat dari Tingkat Kemampuan Guru mengelola pembelajaran sebesar 4,55 dengan rincian rata-rata per aspek pada kedua pertemuan yaitu aspek pendahuluan sebesar 4,81, kegiatan inti sebesar 4,45, penutup sebesar 4,50, pengelolaan waktu sebesar 4,50, dan suasana kelas sebesar 4,50.

Rata-rata total persentase aktivitas siswa yang mendukung pembelajaran $98,70 \%$ sesuai dengan waktu ideal yang ditetapkan artinya persentase aktivitas siswa yang mendukung pembelajaran lebih besar dari persentase aktivitas siswa yang tidak mendukung pembelajaran. Hasil analisis kedua data ini mengindikasikan bahwa LKS dengan pendekatan etnomatematika praktis untuk digunakan dalam pembelajaran.

b. Keefektifan LKS

Keefektifan LKS terpenuhi dilihat dari hasil perolehan perhitungan ketuntasan belajar klasikal yang menunjukkan bahwa rata-rata $85,19 \%$ siswa telah tuntas belajar secara individu, dengan jumlah ketuntasan individu sebanyak 23 orang.

Selanjutnya pada sebaran angket respon siswa, rata-rata 94,07\% siswa senang terhadap komponen pembelajaran, $71,11 \%$ siswa menilai komponen pembelajaran adalah baru, $100 \%$ siswa berminat dengan pembelajaran yang dilakukan, 87,03\% siswa memahami dengan jelas bahasa yang digunakan, dan $100 \%$ siswa tertarik terhadap penampilan LKS. Rata-rata total respon siswa sebesar 87,94\% dengan kriteria sangat positif. Hasil analisis kedua data ini menunjukkan bahwa LKS efektif untuk digunakan dalam pembelajaran.

\section{Optimalisasi Skemata Siswa}

\section{A. Analisis Optimalisasi Skemata Siswa}

Analisis optimalisasi skemata siswa dilakukan dengan membandingkan ketercapaian skemata siswa pada LKS 1 dan LKS 2 berdasarkan hasil pekerjaan kelompok. Dari hasil analisis data diperoleh total rata-rata penyelesaian LKS 1 sebesar 3,00 dengan kriteria "cukup sesuai" dengan skemata siswa, dan LKS 2 sebesar 3,58 dengan kriteria "sangat sesuai" dengan skemata siswa. Hasil analisis ini menunjukkan perolehan rata-rata ketercapaian skemata siswa pada hasil penyelesaian LKS 2 lebih besar dari rata-rata LKS 1.

\section{B. Deskripsi Skemata Siswa}

\section{Deskripsi skemata siswa pada pertemuan I}

Berdasarkan hasil pengisian LKS salah satu kelompok siswa berikut diketahui bahwa siswa dapat menggunakan skematanya pada setiap tahapan dalam mengkonstruksi konsep abstrak matematika. Skema awal yang sudah dimiliki siswa adalah bentuk kabi (tempat sirih pinang) yang biasanya digunakan di lingkungannya. 


\section{Range: Jurnal Pendidikan Matematika Vol. 2 No. 1 Tahun 2020 Maria Dionesia Kofi, dkk.}

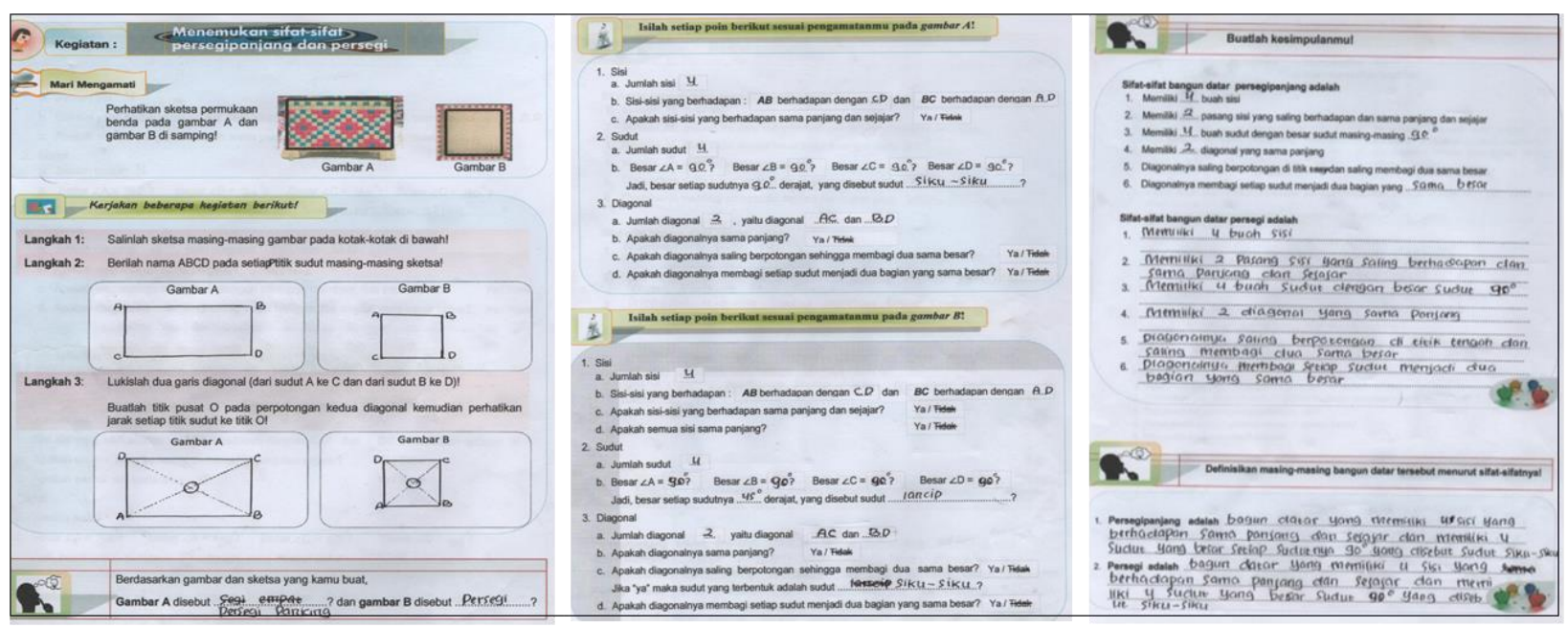

Gambar 5. Hasil pekerjaan siswa pada LKS 1

Pada lembar pertama, siswa melakukan asimilasi dengan mencocokkan gambar permukaan kabi yang berbentuk persegipanjang dan persegi pada LKS dengan bentuk kabi yang sudah sering dilihatnya. Pada langkah pertama dan kedua siswa mampu melakukan akomodasi awal dengan menyalin/menggambar ulang sketsa permukaan kabi pada LKS. Pada langkah ketiga terjadi akomodasi di mana siswa membuat diagonal pada bidang persegi panjang dan persegi kemudian memberi nama yang sesuai dengan setiap bangun yang digambar. Siswa juga memanfaatkan skema yang sudah dimiliki di Sekolah Dasar pada tahap ini.

Pada lembar kedua, siswa menggunakan informasi-informasi yang sudah diperoleh sebelumnya pada lembar pertama dengan mengamati sisi, sudut, dan diagonal persegipanjang dan persegi untuk menjawab beberapa pertanyaan penuntun. Terdapat dua jawaban yang kurang tepat, yang dimungkinkan oleh adanya informasi baru yang tidak sesuai dengan skema siswa. Namun beberapa jawaban lain yang tepat menunjukkan bahwa siswa dapat melakukan akomodasi untuk menyelesaikan LKS pada lembar kedua ini.

Pada lembar ketiga, siswa membuat kesimpulan tentang sifat-sifat persegipanjang dan persegi. Terjadi proses asimilasi yaitu siswa merespon bagian ini berdasarkan skematanya pada lembar kedua, kemudian mendefinisikan persegipanjang dan persegi berdasarkan sifat-sifat yang telah ditemukan.

Penggunaan skemata ini juga tercapai di mana pada saat presentasi, seorang siswa memberi tanggapan terhadap kesimpulan yang salah dari kelompok lain terhadap sifat persegi, dapat di lihat pada percakapan dari transkrip video berikut.

Siswa 1 : "Jadi, besar setiap sudutnya $45^{\circ}$, yang disebut sudut siku-siku....."

Siswa 2 : Besar sudut $45^{\circ}$ disebut sudut lancip bukan sudut siku-siku.

Dari uraian di atas, secara keseluruhan siswa dapat menggunakan skematanya dalam menyelesaikan LKS.

2. Deskripsi skemata siswa pada pertemuan II

Skema siswa terhadap sifat-sifat persegipanjang dan persegi telah dikonstruksi pada pembelajaran sebelumnya. Didukung dengan skema awal siswa terhadap benda-benda dalam budayanya seperti tikar dan tenunan, selanjutnya digunakan siswa untuk menyelesaikan masalah nyata seperti yang terlihat pada penyelesaian LKS berbasis etnomatematika berikut. 


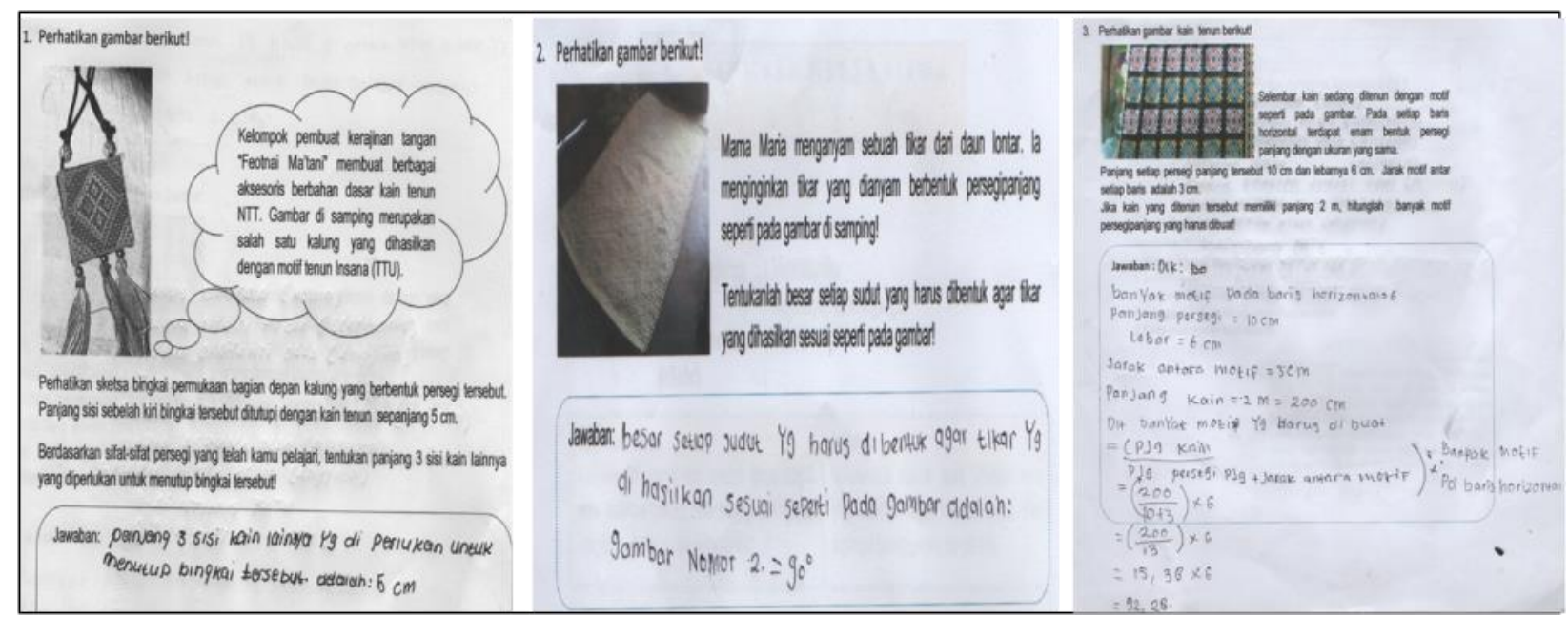

Gambar 6. Hasil pekerjaan siswa pada LKS 2

Pada soal nomor 1, sketsa bingkai permukaan kalung berbentuk persegi ditutupi kain tenun yang panjang salah satu sisinya sudah diketahui yaitu $5 \mathrm{~cm}$. Siswa menggunakan skema tentang sifat-sifat persegi untuk bisa menentukan panjang panjang kain pada ketiga sisi lainnya. Berikut transkrip video saat guru mengarahkan salah satu kelompok siswa untuk dapat menjawab soal nomor 1.

Percakapan 1:

Guru : "Salah satu sifat persegi adalah apa? Keempat sisinya bagaimana?"

Siswa : "Sama panjang"

Percakapan 2:

Guru : "Keempat sisinya sama panjang. Itu kata kuncinya. Jadi kalau dari sini ke sini $10 \mathrm{~cm}$ dari sini ke sini berapa? (sambil menunjuk meja dan meneruskan dengan menunjuk bagian lainnya)"

Guru :"Berarti ketiga sisinya berapa $\mathrm{cm}$ ?"

Siswa : "10 cm"

Percakapan 3:

Guru : "Sehingga kalian bisa lihat di sini; panjang sisi sebelah kiri ditutupi kain tenun dengan panjang $5 \mathrm{~cm}$. Jika ini $5 \mathrm{~cm}$ (sambil menunjuk $L K S$ ), maka ketiga sisi lainnya berapa cm?"

Siswa : "5 cm"

Berdasarkan percakapan ini, berikut diringkas bagaimana siswa menggunakan skematanya dalam tabel 3.

Tabel 3. Alur Skema Siswa

\begin{tabular}{|c|c|c|}
\hline $\begin{array}{l}\text { Penyesuaian skema siswa dengan stimulus/ } \\
\text { (cocok / tidak cocok) }\end{array}$ & Implikasi & $\begin{array}{c}\text { Proses } \\
\text { kognitif }\end{array}$ \\
\hline \multicolumn{3}{|l|}{ Percapakan 1} \\
\hline $\begin{array}{l}\text { Siswa menyesuaikan pertanyaan guru dengan Cocok } \\
\text { skema awal (panjang setiap sisi persegi sama) }\end{array}$ & $\begin{array}{l}\text { Siswa menjawab dengan } \\
\text { benar }\end{array}$ & ilasi \\
\hline \multicolumn{3}{|l|}{ Percakapan 2} \\
\hline $\begin{array}{l}\text { Guru menambahkan informasi baru yaitu ukuran Cocok } \\
\text { sisi } 10 \mathrm{~cm} \text {. Siswa menyesuaikan skema awal } \\
\text { dengan informasi baru ini }\end{array}$ & $\begin{array}{l}\text { Siswa menciptakan skema } \\
\text { baru yaitu panjang setiap } \\
\text { sisi sama } 10 \mathrm{~cm}\end{array}$ & Akomodasi \\
\hline \multicolumn{3}{|l|}{ Percakapan 3} \\
\hline $\begin{array}{l}\text { Guru mengaitkan gambaran awal ini } \\
\text { informasi berupa soal dalam LKS. } \\
\text { menyesuaikan skema dari percakapan } 2 \\
\text { dengan } \\
\end{array}$ & $\begin{array}{l}\text { Siswa menjawab dengan } \\
\text { benar }\end{array}$ & odasi \\
\hline
\end{tabular}




\section{Range: Jurnal Pendidikan Matematika Vol. 2 No. 1 Tahun 2020 Maria Dionesia Kofi, dkk.}

informasi baru

Ketiga proses ini sampai pada titik di mana siswa menemukan jawaban yang tepat, artinya siswa mencapai titik keseimbangan dari proses asimilasi dan akomodasi yang juga dapat dilihat pada hasil pekerjaan siswa.

Pada soal nomor 2, siswa harus menentukan besar sudut yang harus dibentuk untuk membuat tikar agar bentuknya menyerupai persegipanjang seperti tikar pada gambar. Siswa menggunakan pengetahuan awal tentang sifat-sifat persegi panjang untuk dapat menjawab soal ini. Berikut transkrip cuplikan video di mana salah satu siswa menemukan kesimpulan yang benar.

Siswa: (Setelah membaca soal) "Persegipanjang. Persegipanjang itu $90^{\circ}$. Berarti sudut pada tikar yang diberikan, setiap sudut $90^{0}$ ".

Berikut diringkas bagaimana siswa ini menggunakan skematanya dalam tabel 4 .

Tabel 4. Alur skema siswa

\begin{tabular}{lllc}
\hline $\begin{array}{c}\text { Penyesuaian skema siswa dengan stimulus/ } \\
\text { (cocok/ tidak cocok) }\end{array}$ & \multicolumn{1}{c}{ Implikasi } & $\begin{array}{c}\text { Proses } \\
\text { kognitif }\end{array}$ \\
\hline $\begin{array}{l}\text { Siswa membaca soal nomor 2 yang merupakan } \\
\text { informasi baru. Kemudian menyesuaikan skema }\end{array}$ & cocok & $\begin{array}{l}\text { Siswa mengatakan tikar } \\
\text { berbentuk persegi panjang }\end{array}$ & Asimilasi \\
awal dengan informasi baru ini. & & Siswa mengatakan besar & Asimilasi \\
\hline $\begin{array}{l}\text { Siswa mengatakan itu persegipanjang, dan cocok } \\
\text { menyesuaikan dengan skema awal tentang besar }\end{array}$ & & $\begin{array}{l}\text { sudut persegipanjang } 90^{\circ} \\
\text { sudut persegi panjang yaitu 90 }\end{array}$ & \\
\hline $\begin{array}{l}\text { Siswa mengaitkan sifat persegipanjang ini dengan cocok } \\
\text { informasi baru berupa pertanyaan dalam LKS. }\end{array}$ & $\begin{array}{l}\text { Siswa menyimpulkan } \\
\text { dengan benar yaitu setiap }\end{array}$ & Akomodasi \\
$\begin{array}{l}\text { Kemudian siswa menyesuaikan dengan skema } \\
\text { awal bahwa besar sudut persegipanjang itu } 90^{\circ}\end{array}$ & $\begin{array}{l}\text { sudut yang harus dibentuk } \\
\text { pada tikar adalah } 90^{\circ}\end{array}$ & \\
\hline
\end{tabular}

Di sini juga terjadi keseimbangan yaitu siswa mampu melakukan asimilasi dan akomodasi sehingga dapat menyimpulkan dengan benar.

Pada soal nomor 3, siswa diminta menghitung banyak motif persegipanjang yang harus dibuat pada kain tenun sepanjang $2 \mathrm{~m}$. Dalam mengerjakan soal ini, siswa kurang dapat melakukan akomodasi terhadap informasi baru di antaranya; terdapat 6 bentuk persegi panjang pada baris horizontal dengan ukuran yang sama yaitu $10 \mathrm{~cm} \times 6 \mathrm{~cm}$, dan jarak motif persegipanjang antar baris $3 \mathrm{~cm}$. Akibatnya siswa tidak dapat menentukan langkah penyelesaian. Hal ini juga dikarenakan siswa belum memiliki skema terhadap langkah-langkahnya sehingga guru memberi banyak arahan untuk membantu siswa mulai dari langkah awal sampai akhir. Namun di sini tetap terlihat bahwa siswa memanfaatkan skema lain yang sudah ada untuk menyelesaikan soal ini yaitu operasi bilangan (perkalian, pembagian, dan penjumlahan).

\section{Pembahasan}

Pengembangan LKS menggunakan konteks anyaman dan tenunan masyarakat TTU ini telah menghasilkan LKS yang valid, praktis, dan efektif. Penggunakan LKS yang dikembangkan ini memberi pengaruh positif dalam pembelajaran karena siswa belajar dari objek-objek yang sudah sering ditemui dalam budayanya untuk dapat menemukan konsep-konsep abstrak dalam matematika. Sebagaimana Matang (2002 : 35) dalam hasil penelitiannya bahwa etnomatematika memiliki peran untuk memahami konsep abstrak matematika. Pencapaian kategori LKS (valid, praktis, efektif) ini diringkas dalam tabel berikut.

Tabel 2. Pencapaian Kategori LKS

\begin{tabular}{|c|l|l|}
\hline \multicolumn{1}{|c|}{ Kategori } & \multicolumn{1}{|c|}{ Sumber Data } & \multicolumn{1}{c|}{ Keterangan } \\
\hline Kevalidan & Validasi ahli & Valid \\
\hline \multirow{2}{*}{ Kepraktisan } & Kemampuan guru mengelola pembelajaran & Sangat baik \\
\cline { 2 - 3 } & Aktivitas siswa & Efektif \\
\hline Keefektifan & Respon siswa & Sangat positif \\
\hline
\end{tabular}




\section{Range: Jurnal Pendidikan Matematika Vol. 2 No. 1 Tahun 2020 Maria Dionesia Kofi, dkk.}

Tes Hasil belajar Memenuhi ketuntasan klasikal

Penggunaan LKS berbasis etnomatematika yang valid, praktis, dan efektif ini dapat mengoptimalkan skemata siswa. Sebagaimana dapat dilihat dari hasil analisis optimalisasi skemata siswa dengan perolehan rata-rata ketercapaian skemata siswa pada penyelesaian LKS 1 (pertemuan pertama) sebesar 3,00 dan terjadi peningkatan pada penyelesaian LKS 2 (pertemuan kedua) sebesar 3,58. Selanjutnya pada deskripsi penggunaan skemata siswa pada setiap pertemuan menunjukkan siswa menggunakan skematanya dalam mengerjakan LKS melalui proses asimilasi dan akomodasi.

\section{Keimpulan}

Berdasarkan hasil dan pembahasan yang telah diuraikan dapat disimpulkan bahwa penggunaan LKS berbasis etnomatematika yang valid, praktis, dan efektif dapat mengoptimalkan skemata siswa. Peneliti menyarankan kepada para guru agar dalam kegiatan pembelajaran dapat menggunakan LKS yang dirancang menggunakan pendekatan etnomatematika.

\section{Daftar Pustaka}

Amsikan, S. \& Deda, Y.N. 2018. Memanfaatkan potensi lokal kefamenanu dalam pembelajsrsn matematika untuk meningkatkan kreativitas guru SMP. Bakti Cendana:Jurnal Pengabdian Masyarakat, 1(1), (pp. 32-40).

Ar, H.E.S. \& tim. (2001). Strategi Pembelajaran Matematika Kontemporer. Bandung: JICA.

Deda, N. Y, Amsikan, S. 2019. Geometry Concept on the Motifs of Woven Fabric in Kefamenanu Community. JRAMathEdu: Journal of Advances of Mathematics Education, 4(1), (pp. 23-30).

Deda, Y. N. \& Disnawati, H. (2017). Hubungan Motif Kain Tenun Masyarakat Suku Dawan - Timor dengan Matematika Sekolah. Prosiding KNPM II, 2017, (pp.201-209)..

Disnawati, H. \& Nahak, S. (2019). Pengembangan Lembar Kerja Siswa Berbasis Etnomatematika Tenun Timor pada Materi Pola Bilangan. Jurnal Elemen, 5(1), (pp.64-79).

Funan, F.X. \& Mamoh, O. (2019). Eksplorasi Etnomatematika Uem Le'u Insana dalam Kaitannya dengan Konsep Geometri. Range: Jurnal Pendidikan Matematika, 1(1), (pp.56-69).

Hardiarti, S. (2017). Etnomatematika: Aplikasi Bangun Datar Segiempat pada Candi Muaro Jambi. Aksioma, 8(2), (pp.99-110).

Hergenhahn, B.R. \& Olson, M.H. (2008). Theories Of Learning (Teori Belajar). Jakarta: Kencana.

Iskandar, R.S.F. \& Raditya, A. (2017). Pengembangan Bahan Ajar Project Based Learning Berbantuan SCRATCH. Seminar Nasional Matematika dan Aplikasinya, 2017, (pp.167-172).

Mamoh, O. (2016). Pengembangan Perangkat Rencana Pelaksanaan Pembelajaran Matematika Realistik Untuk Materi Transformasi pada Siswa Kelas VII SMP. Jurnal Sains dan Teknologi, 8(2), (pp.1223).

Matang, R. (2002). The Role of Ethnomathematics in Mathematics Education in Papua New Guinea: Implications for mathematics curriculum. Journal of Educational Studies, 24(1), (pp.27-37).

Rasyid, M.A., Budiarto, M.T., \& Lukito, A. (2017). Profil Berpikir Reflektif Siswa SMP dalam Pemecahan Masalah Pecahan Ditinjau dari Perbedaan Gender. Jurnal Matematika Kreatif-Inovatif, 8(2), (pp.171-181).

Richardo, R. (2016). Peran Ethnomatematika Dalam Penerapan Pembelajaran Matematika Pada Kurikulum 2013. LITERASI, 7(2), (pp.118-125).

Rochmad. (2012). Desain Model Pengembangan Perangkat Pembelajaran Matematika. JURNAL KREANO, 3(1), (pp.59-72).

Trianto. (2010). Model Pembelajaran Terpadu. Jakarta: PT Bumi Aksara. 